\title{
Burying Ground
}

\author{
Jennifer $\mathrm{Hu}^{1}$
}

Published online: 20 September 2016

(C) Springer Science+Business Media New York 2016

There are other better thoughts -

rice paddies, maple forests, eggs still warm from the hen.

These days are cool enough for fourteen-mile hikes around the thickest part of the lake. The walk is a quiet joy.

At night, your breath rushes out like pulled white cotton, the cold surrendering.

A fun fact to share on first dates: your favorite color is warm apple cider, second only to light on water, third only to frost. When you were a child, your grandmother rolled sticks of sugar-coated fruit in the snow and sold them as popsicles. Funny what memory can do -

I watch you watching yourself, your eyes staring past the kitchen window.

At some point, you slipped out of your skin to become the third person now, a consideration of your body, your own unfamiliar hands spearing the purple plum.

Every February, our mistakes are swept away during New Year's cleaning, all wrongs forgiven with the melting snow. Dumpling flour coats your fingers.

The ink on the hung paper dries. The sun is red.

Your eyes - now young, now hazy, now like your father's before he died a good death, an accomplishment worth the work.

I can tell you, too, are not afraid of the effort. I see you practicing the half-smile, your small peace in folded hands, one last contented breath the perfected manner in which you will leave us so we will believe you had no regrets and we have done everything right.

Jennifer $\mathrm{Hu}$

Jennifer_hu@urmc.rochester.edu 